\title{
INVENTARISASI GASTROPODA DI LANTAI HUTAN MANGROVE DESA RAP-RAP KABUPATEN MINAHASA SELATAN SULAWESI UTARA
}

\author{
Jety K. Rangan \\ Staf Pengajar pada Program Studi Manajemen Sumberdaya Perairan, \\ Fakultas Perikanan dan IImu Kelautan. UNSRAT. Manado 95115.
}

\author{
ABSTRACT \\ Rangan, J.K., 2010. Inventory Gastropoda in the Floor of Mangrove Forest \\ Rap Rap Village South Minahasa Regency of North Sulawesi. \\ Jurnal Perikanan dan Kelautan. Vol VI (1): 63-66.
}

\begin{abstract}
The mangrove forest is a transitional ecosystem between land and sea. As a transition area between land and sea, mangrove forest ecosystems have environmental properties of a sharp gradient. Tides can result in changes in several environmental factors, mainly temperature and salinity. One type of animal that can tolerate these environmental changes are of a group of mollusks. The purpose of this study was to identify the types of mollusks (Gastropoda) found on the floor of Mangrove Forest, using transects squares drawn perpendicular from the shoreline mangrove cutting edge.

From this research activity gastropods found in the floor of mangrove forest-Rap Rap village consists of five phyla, and nine species, namely: Family Cerithiidae, namely Cerithium cobelty and Clypeomorus coralium. Family Littorinidae are Littoraria scabra, family Muricidae are Chicoreus capucinus, and morula margariticola Drupella rugosa, from the family of Nassarius Nassariidae Potamididae margaritifer and family, namely Telescopium telescopium and Terebralia sulcata.
\end{abstract}

Keywords: Gastropoda, Mangrove Forest, Rap Rap Village.

\section{PENDAHULUAN}

Lautan merupakan lingkungan hidup yang sangat luas, di dalamnya terkandung sumberdaya yang berlimpah jumlahnya dan mempunyai potensi yang besar dan dicirikan dengan ekosistem khas seperti terumbu karang, lamun dan hutan mangrove. Hutan mangrove merupakan ekositem peralihan antara daratan dan lautan, juga mempunyai manfaat ganda serta merupakan mata rantai yang sangat penting dalam memelihara kesinambungan siklus biologi suatu perairan.

Ekosistem hutan mangrove dapat menyediakan habitat yang baik bagi kolonisasi berbagai fauna yaitu dengan adanya naungan, substrat dasar yang lembab, pohon sebagai tempat menempel dan yang terpenting yaitu kelimpahan detritus organic sebagai makanan (Kusrini, 1988). Selanjutnya mereka membagi fauna hutan mangrove berdasarkan habitatnya yaitu: (1) Fauna yang hidup di atas permukaan tanah (surface fauna/epifauna), (2) Fauna yang hidup meliang di dalam tanah (infauna) dan (3) Fauna yang hidup menempel di pohon mangrove.

Reksodihardjo $d k k$ (1986), mengemukakan bahwa salah satu gastropoda yang mendominasi ekosistem mangrove adalah dari family Potamididae. Keong Potamididae merupakan penghuni asli hutan mangrove dan hidup di daerah yang terkena pasang surut serta menyukai areal berlumpur (Heryanto $d k k, 1986$ ).

Peranannya di lingkungan biota dapat dilihat dari kehadiran berbagai biota yang menggunakan hutan mangrove sebagai tempat memijah, asuhan, pembesaran, mencari makan, bernaung, persembunyian dari berbagai macam biota (Supriharyono, 2000). Budiman (1991) dalam Potalangi (1997) membagi jenis-jenis moluska yang hidup di hutan mangrove menjadi tiga kelompok sebagai berikut: 
1. Jenis-jenis moluska asli hutan mangrove, adalah jenis moluska yang seluruh dan sebagian besar waktu hidup dewasanya dihabiskan di hutan mangrove umumnya merupakan pemakan serasah, dengan sebaran dari bagian tengah sampai ke belakang hutan mangrove.

2. Jenis-jenis moluska fakultatif, adalah jenis moluska yang menggunakan hutan mangrove sebagai salah satu tempat hidupnya. Umumnya hidup di bagian pinggiran hutan, baik ke arah pantai atau ke arah darat.

3. Jenis-jenis moluska pengunjung, adalah jenis-jenis yang secara tak sengaja di dalam hutan mangrove. Umumnya hadir di sekitar perbatasan antara hutan dan ekosistem tempat hidupnya.

Salah satu kelompok moluska penyusun fauna mangrove adalah gastropoda (Kartawinata dkk, 1979 dalam Boneka, 1993).

Berdasarkan latar belakang dan kurangnya informasi tentang gastropoda di lantai hutan mangrove maka tujuan penelitian ini adalah untuk menginventarisir jenis gastropoda yang terdapat di lantai hutan mangrove desa Rap-rap, Kabupaten Minahasa Selatan.

\section{METODE PENELITIAN}

Pengambilan sampel gastropoda menggunakan metode transek kuadrat yang ditarik tegak lurus garis pantai dari mangrove terdepan. Transek yang digunakan berjumlah 3 buah yang ditarik sejajar satu dengan yang lainnya dengan jarak 50 meter, jarak antar transek yang satu dengan yang lain sebesar 5 meter, dengan demikian total jumlah kuadrat 30 buah.

Pengambilan sampel gastropoda dilakukan dengan mengambil semua gastropoda yang berada di lantai hutan mangrove, menempel pada batang kayu yang telah mati dan pada akar yang berada dalam luasan pengambilan sampel. Sampel diawetkan dengan menggunakan alcohol $70 \%$, selanjutnya sampel diidentifikasi dengan menggunakan buku identifikasi oleh Abbot (1991), Abbot dan Dance (1991), Dharma (1988), Dharma (1992) dan Roberts, dkk(1982). Data yang dicatat meliputi jumlah individu masing-masing spesies pada setiap kuadrat.

\section{HASIL DAN PEMBAHASAN}

Gastropoda yang ditemukan di lantai hutan mangrove desa Rap-rap terdiri dari 5 Famili dan 9 spesies (Tabel 1) dan masing-masing jumlah spesies untuk setiap transek dapat dilihat pada Tabel 2-4.

Tabel. 1. Gastropoda yang ditemukan di lantai hutan mangrove Desa Rap-rap

\begin{tabular}{ccll}
\hline No & Famili & \multicolumn{1}{c}{ Genus } & \multicolumn{1}{c}{ Spesies } \\
\hline 1 & Cerithiidae & Cerithium & Ceritium kobelti \\
& & Clypeomorus & Clypeomorus coralium \\
2 & Littorinidae & Littoraria & Littoraria scabra \\
3 & Potamididae & Telescopium & Telescopium telescopium \\
& & Terebralia & Terebralia sulcata \\
4 & Muricidae & Chicoreus & Chicoreus capucinus \\
& & Drupella & Drupella rugosa \\
& & Morula & Morula margariticola \\
5 & Nassaridae & Nassarius & Nassarius margaritifer \\
\hline
\end{tabular}


Tabel 2. Komposisi Gastropoda pada Transek 1

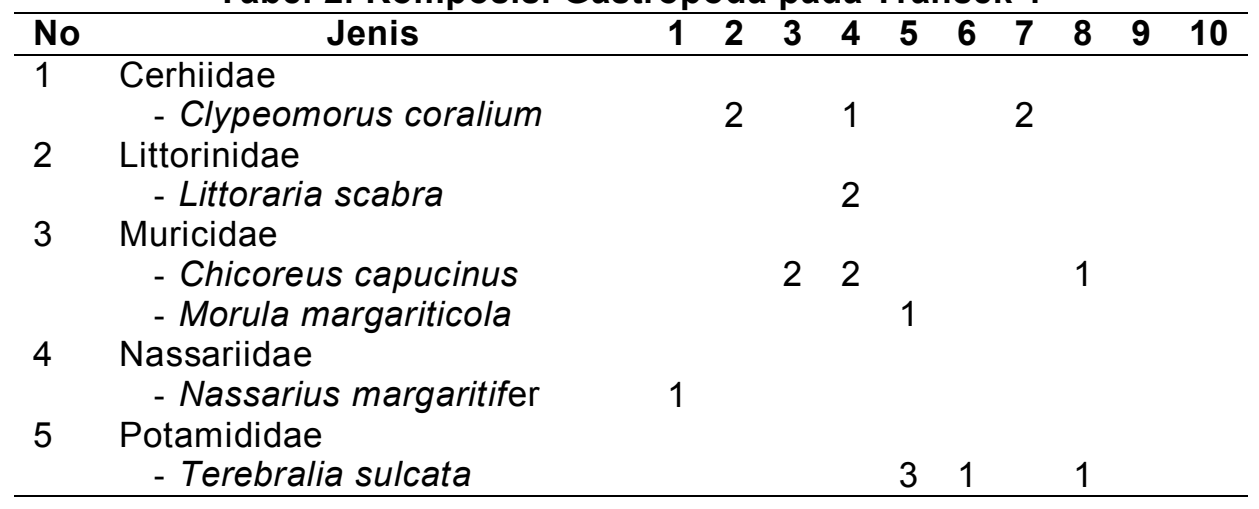

Tabel 3. Komposisi Gastropoda pada Transek II

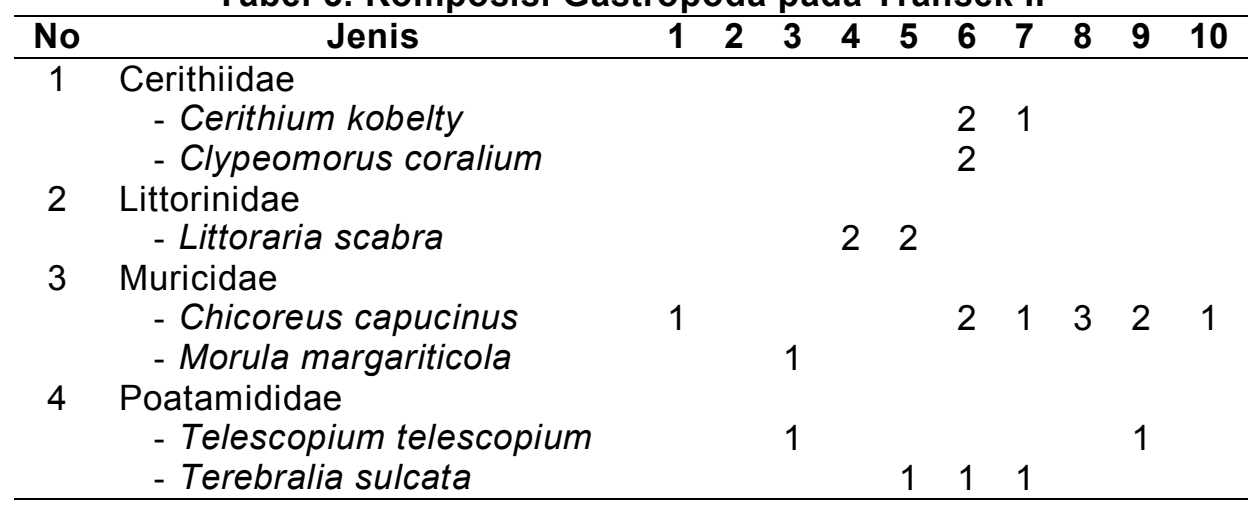

Tabel 4. Komposisi Gastropoda pada Transek III

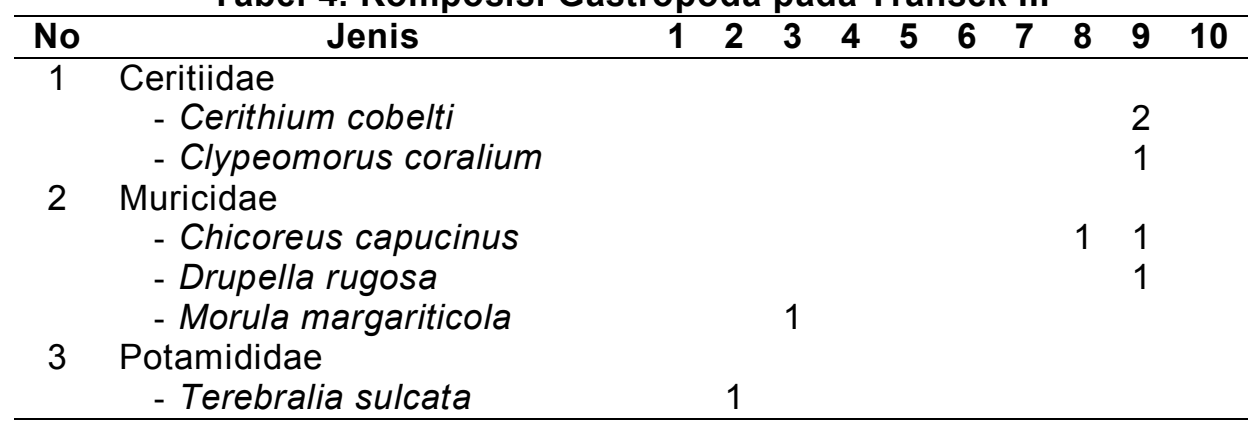

Dari 9 spesies yang ditemukan yang terbanyak adalah spesies Chicoreus capucinus dari family Muricidae yaitu sebanyak 17 individu. Pada transek 1 keberadaan mangrove tidak terlalu banyak sehingga jumlah gastropoda yang ditemukan sedikit, pada transek 3 berada dekat daerah pemukiman dimana mangrove di daerah ini banyak yang telah dieksploitasi mengakibatkan kurangnya moluska khususnya moluska, sedangkan pada transek 2 kondisi mangrove cukup padat sehingga gastropoda yang ditemukan lebih banyak dari ke dua transek yang lain.

Chicoreus capucinus, Terebralia sulcata, Clypeomorus coralum, Littoraria scabra, Telescopium telescopium merupakan jenis asli penghuni hutan mangrove dan memiliki toleransi yang tinggi terhadap perubahan kondisi lingkungan. Karenanya hanya hewan-hewan dan tumbuhan yang memiliki toleransi yang besar terhadap perubahan ekstrim dari faktor-faktor fisik yang dapat bertahan dan berkembang di hutan mangrove (Plaziat, 1984).

Chicoreus capucinus ditemukan paling banyak, hal ini disebabkan spesies ini lebih menyukai daerah yang berbatasan langsung dengan laut, hal ini pula 
mendukung pernyataan Sabar dkk (1978), yang menyatakan bahwa C. capucinus hidup pada lumpur basah sekitar pangkal pohon mangrove.

Terebralia sulcata banyak hidup di lantai hutan dan juga menempel pada batang-batang sampai pada ketinggian lebih dari 1 meter (Reksodihardjo, 1986) sedang spesies Telescopium telescopium lebih menyukai daerah yang berlantai lumpur berair dengan genangan-genangan air di sekitarnya yang kaya akan sisasisa bahan organic berupa detritus (Kusrini, 1988).

Famili Cerithiidae, yaitu Clypeomorus coralium ditemukan pada tempat yang teduh dengan vegetasi mangrove yang lebat dan rimbun untuk menghindari kekeringan. Drupella rugosa dan Nassarius margaritifer masing-masing hanya ditemukan 1 individu, hal ini disebabkan karena spesies tersebut bukan penghuni asli di hutan mangrove melainkan jenis fakultatif, hanya sebagai pengunjung di hutan mangrove.

\section{KESIMPULAN}

Berdasarkan hasil inventarisasi gastropoda di lantai hutan mangrove Rap-rap ditemukan sebanyak 5 famili dan 9 spesies. Spesies yang mendominasi daerah tersebut adalah Chicoreus capucinus, Clypeomorus coralium dan Terebralia sulcata dari family Muricidae.

\section{DAFTAR PUSTAKA}

Abbot, R.T., 1991. Seashell of South East Asia. Graham Brash Singapore Lushal.

Abbot, R.T., dan Dance, S.P., 1991. Compendium of Seashells American Malacologist. Inc Melbourne. Burlington.

Boneka, S.S., 1993. Distribusi Gastropoda di Hutan Mangrove. Desa Tongkeina Kec. Molas. Kodya Manado, Sulawesi Utara. Skripsi. FPIK. UNSRAT Manado.

Dharma, B., 1988. Siput dan Kerang Indonesia I (Indonesian Shells). PT. Sarana Graha. Jakarta

Dharma, B., 1992. Siput dan Kerang Indonesia II (Indonesian Shells). PT. Sarana Graha. Jakarta.

Heryanto, A. Budiman dan D. Sapulete. 1989. Beberapa Parameter Ekologi Moluska Hutan Magrove di Saumlaki, Tanimbar Selatan dalam Prosiding Seminar Ekosistem Mangrove di Bali.

Plaziat, J.C. 1984. Molusca Distribution In the Mangal. Hydrobiologi of the Mangal. Dr. W. Junk Publishae. The House.

Potalangi, M.R. 1997. Beberapa Aspek Bioekologi Keong Potamididae di Hutan Mangrove. Makalah FPIK UNSRAT.

Reksodihardjo, G., Y. Irmawati dan D.S. Moro. 1986. Pola Sebaran Moluska Suku Potamididae di Hutan Lego Lentah Pulau Panaitan dalam Prosiding Seminar III Ekosistem Mangrove. Denpasar Bali. 